\title{
Growth response of seedlings of zea mays (L.) to aqueous extract of lycopodium clavatum (L.)
}

\begin{abstract}
The growth response of seedlings of Zea mays to aqueous extract of Lycopodium clavatum was assayed in the greenhouse using completely randomized design (CRD) with three replicates and five treatments. Seeds of Zea mays were grown in Petri dishes measuring $9 \mathrm{~cm}$ wrapped with whatmam filter paper. The test treatments were aqueous extracts of $L$. clavatum leaves at different concentrations of $0 \%, 25 \%, 50 \%, 75 \%$ and $100 \%$. Extracts showed both inhibitory and stimulatory effect on Zea mays seedling growth at different concentrations. The plumule length and radicle length were measured using a ruler. $L$. clavatum showed stimulatory effect at $25 \%$ concentration only and inhibitory effect at $50 \%$, $75 \%$ and $100 \%$. Radicle length decreased with increase in concentration with the highest length recorded in the $0 \%$ concentration (control) whereas the plumule length increased over the measurement period and also decreased with increase in concentration.
\end{abstract}

Keywords: allelopathy, inhibition, stimulation, plumule length, radicle length
Volume 2 Issue 4 - 2017

\begin{abstract}
Akpan EN, Denise EM, Ezendiokwelu EL, Anyadike MC

Department of Botany and Ecological Studies, University of UYO, Nigeria
\end{abstract}

\author{
Correspondence: Denise EM, Department of Botany and \\ Ecological Studies, University of UYO, \\ P.M.B. 1017 Uyo, Akwa Ibom State, Nigeria, Tel \\ 08067043869/08027038198, \\ Email Mukoroemmanuel0I@gmail.com, elsieudoh@gmail.com
}

Received: December 04, 2017 | Published: December 2I, 2017

\section{Introduction}

Natural selection is a phenomenon, which allows nature to select at any point in time the structure and number of organism living in a particular habitat. ${ }^{1}$ This competitive tendency has been shown and reported by several authors Bonner, ${ }^{2}$ Grummer et al. ${ }^{3}$ Evenari (1961), Whittaker, ${ }^{4}$ Putman et al., ${ }^{5}$ and Fischer et al. ${ }^{6}$ Allelopathic behaviour can best be described as direct or indirect effects of compound resulting from organism, which may have inhibitory or stimulatory effects on the same or other organisms. In this process, synthesis of biologically active molecules produced by plant and their residue may be converted to other forms and influenced the growth of similar or non-similar plants. ${ }^{7}$ The earliest writings on this topic are attributed to Theophrastus (ca.300 B.C), a successor of Aristotle who noticed the harmful effects of cabbage on a vine and suggested that such effects were caused by odours from the cabbage plants. This phenomenon is known as allelopathy (from the Greek allelon=of each other, pathós=to suffer). The term, Allelopathy was first introduced by Molich in 1937. He defined it as reciprocal effects of biochemical compounds among all plants and microorganism. Typical allelopathic inhibitory effects result from the action of groups of allelochemicals that collectively interfere in various physiological processes altering the growth patterns of plants. ${ }^{8-10}$ Allelochemicals may be involved in plant-plant, plant-insect or plant-herbivore chemical communication ${ }^{11}$ as well as microorganism-derived allelochemicals that may be involved in microbe-microbe or microbe-plant interactions (e.g., colonisation process of a new environment). ${ }^{12}$ The inhibition of root growth and development by allelochemicals can be due to changes in DNA synthesis in cells of apical root meristem, alteration of the mitochondrial metabolism ${ }^{13}$ or changes in cell mitotic indices. ${ }^{14-17}$

L. clavatum, commonly known as Club moss, Clubfoot Moss, Foxtail, Ground Pine, Sulfer or Wolf's Claw is one of the most widespread species belonging to family Lycopodiaceae. It is a pteridophyte which is abundantly found in tropical, subtropical and in many European countries. Clubmoss is used in homeopathy for treatments of aneurisms, constipation, chronic lung and bronchial disorders, fevers. It also reduces gastric inflammations, simplifies digestion and helps in treatments of chronic kidney disorders
(Zimudzi and Bosch 2007). Maize has become a staple food in many parts of the world, with total production surpassing that of wheat or rice. However, not all of this maize is consumed directly by humans. Some of the maize production is used for corn ethanol, animal feed and other maize products, such as corn starch and corn syrup. The six major types of corn are dent corn, flint corn, pod corn, popcorn, flour corn, and sweet corn. ${ }^{18}$

\section{Literature review}

Kaur et al. ${ }^{19}$ demonstrated that benzoic acid produces irregularities in mustard root cells, which were disorganized, inhibiting root growth. Shivani et al. ${ }^{20}$ conducted a study to elucidate the allelopathic effects of lipophilic and aqueous extracts of liverworts on seed germination and seedling growth of a weed, Bidens pilosa. The liverwort species selected for the study were Plagiochasma appendiculatum, Targionia indica, Conocephalum conicum and Dumortiera hirsuta. It was observed that the lipophilic extract had more inhibitory effect on the seedling growth than the aqueous extracts. Cruz-Ortega et al. ${ }^{21}$ studied the influence of aqueous extracts of Sicyos deppei on the cells at the root tips of Phaseolus vulgaris which resulted to stunted and compacted seedlings. Waris et al..$^{22}$ conducted an investigation on the allelopathic effect of methanol and water extracts of camellia sinensis leaves on seed germination and growth of Triticum aestivum and Zea mays. The study describes the possible effects of tea residues on crop production. Analysis of the data revealed that tea extract significantly suppressed seed germination and the growth of wheat and maize. Gatti ${ }^{23}$ conducted a study on the allelopathic effects of aqueous extracts of Aristolochia esperanzae O.Kuntze on development of Sesamum indicum L. seedlings to identify the effects of aqueous extracts of $A$. esperanzae on germination, root growth and xylem cell development of sesame seedlings. Leaf and shoot extracts were prepared at concentrations of 1.5 and 3\%. Extracts caused marked changes in germination and seedling growth with greatest inhibition produced by root extracts. Chaudhuri et al. ${ }^{24}$ conducted a study to determine the effective allelopathic (inhibitory) extract fractions of Ampelocissus latifolia leaf along with preliminary phytochemical screening and to correlate allelopathy with the quantity and quality of total phenolics and with extraction solvents polarity index. Comparative allelopathic 
inhibitory activity of the extract fractions was studied using wheat seedlings and correlated with the qualitative phytochemical analysis and the total phenolics content. The study suggests that A. latifolia is very rich in phytochemicals and the extract had severe allelopathic effect on the seedling growth of wheat.

\section{Materials and methods}

\section{Plant material}

The leaves of L. clavatum were collected from Ita-Enang DamIdidep Ibiono Ibom on $25^{\text {th }}$ May, 2017. The plant was identified in the herbarium of Botany and Ecological Studies University of Uyo. The plants were taken to the Chemistry Laboratory University of Uyo where the extraction processes was conducted.

\section{Aqueous extraction and purification}

The leaves were spread on a plywood sheet and were air-dried for three days at room temperature. The dried leaves were poured into a transparent bucket and 3 litres of distilled water was added. It was allowed to stand for a week and three days so that the contents will properly be extracted. The extract was filtered through a separating funnel stuffed with enough cotton wool and hung on a retort stand to remove debris. The stock concentration was gotten by evaporating the extract using a water bath.

\section{Seed culture and treatment}

Seeds of Zea mays were surface sterilized with water: bleach $(10: 1 \mathrm{v} / \mathrm{v})$ solution for 5 minutes to avoid contamination and were thoroughly rinsed four times with sterile distilled water. For testing, 15 petri dishes ( $9 \mathrm{~cm}$ in diameter), were washed and sterilized with water: bleach $(10: 1 \mathrm{v} / \mathrm{v})$ solution for 3 minutes to avoid contamination, each petri dish were well labeled to avoid mixing up. Whatman No.1 filter papers were kept in each Petri dish, and ten sterilized seeds of Zea mays were placed in each Petri dish at equal distance. Concentrations of $25 \%, 50 \%, 75 \%$ and $100 \%$ were prepared from the stock solution for the extract. $10 \mathrm{ml}$ of each concentration was added to the Petri dishes. Seeds soaked in distilled water were used as control and each of the experiment was repeated two times. $10 \mathrm{ml}$ of each extract and $10 \mathrm{ml}$ of distilled water for control was applied daily during the experiment to keep the Whatman paper moist for seedling development for a period of 14 days. The experiment was conducted at the Botany Green House, University of Uyo, Uyo Akwa-Ibom State Nigeria. During the course of the experiment, data were recorded on the variables mentioned below;

i) Radicle length: Length of radicle (root) length was measured using a ruler in $\mathrm{cm}$.

ii) Plumule length: Length of plumule (shoot) length was measured using a ruler in $\mathrm{cm}$.

\section{Statistical analysis}

Analysis of variance was performed using standard techniques and differences between the means were compared through Duncans multiple Significant Difference test $(\mathrm{P}<0.05)$ using SPSS software package.

\section{Results}

The results of the allelopathic effects of L. clavatum on the seedling growth of Zea mays are shown in Table 1 and Table 2. Table 1 shows that extracts of $L$. clavatum had inhibitory effect on radicle growth at $75 \%$ and $100 \%$ concentrations compared to control over the measurement period. The extract also showed stimulatory effect at $25 \%$ concentration but the treatment with no extract (control) showed the highest radicle length. Table 2 shows that there was no plumule growth on day 2 of the experiment. From the table the plumule length increased over evaluation period. It could also be observed that $25 \%$ concentration showed the highest plumule growth.

Table I Allelopathic effect of $L$. clavatum extract on the radicle length of Zea mays

\begin{tabular}{llllll}
\hline Concentration & Day 2 & Day 4 & Day 8 & Day I2 & Day I4 \\
\hline Control & $0.40 \mathrm{~cm}$ & $1.87 \mathrm{~cm}$ & $1.97 \mathrm{~cm}$ & $2.63 \mathrm{~cm}$ & $2.37 \mathrm{~cm}$ \\
$25 \%$ & $0.50 \mathrm{~cm}$ & $1.20 \mathrm{~cm}$ & $2.40 \mathrm{~cm}$ & $2.13 \mathrm{~cm}$ & $2.23 \mathrm{~cm}$ \\
$50 \%$ & $0.53 \mathrm{~cm}$ & $0.53 \mathrm{~cm}$ & $0.57 \mathrm{~cm}$ & $0.63 \mathrm{~cm}$ & $0.60 \mathrm{~cm}$ \\
$75 \%$ & $0.16 \mathrm{~cm}$ & $0.50 \mathrm{~cm}$ & $0.73 \mathrm{~cm}$ & $1.23 \mathrm{~cm}$ & $1.60 \mathrm{~cm}$ \\
$100 \%$ & 0 & $0.10 \mathrm{~cm}$ & $0.97 \mathrm{~cm}$ & $1.0 \mathrm{~cm}$ & $0.9 \mathrm{~cm}$ \\
\hline
\end{tabular}

Table 2 Allelopathic effect of $L$. clavatum extract on the plumule length of Zea may

\begin{tabular}{llllll}
\hline Concentration & Day 2 & Day 4 & Day 8 & Day 12 & Day 14 \\
\hline Control & 0 & $0.53 \mathrm{~cm}$ & $3.23 \mathrm{~cm}$ & $6.80 \mathrm{~cm}$ & $8.53 \mathrm{~cm}$ \\
$25 \%$ & 0 & $0.50 \mathrm{~cm}$ & $3.57 \mathrm{~cm}$ & $7.80 \mathrm{~cm}$ & $9.17 \mathrm{~cm}$ \\
$50 \%$ & 0 & $0.37 \mathrm{~cm}$ & $0.93 \mathrm{~cm}$ & $1.50 \mathrm{~cm}$ & $2.57 \mathrm{~cm}$ \\
$75 \%$ & 0 & $0.33 \mathrm{~cm}$ & $1.10 \mathrm{~cm}$ & $2.40 \mathrm{~cm}$ & $4.17 \mathrm{~cm}$ \\
$100 \%$ & 0 & 0 & $0.87 \mathrm{~cm}$ & $1.53 \mathrm{~cm}$ & $1.60 \mathrm{~cm}$ \\
\hline
\end{tabular}

\section{Discussion}

\section{Radicle (Root length)}

Data evaluation showed that different concentrations of the extract significantly affected the radicle length of maize $(\mathrm{P}<0.05)$. With increased concentration, the buds root length reduced in comparison with control. It was observed that L. clavatum has more effect on the radicle length with the highest length in control (no extract) and the radicle length decreased with increase in concentration showing that L. clavatum has inhibitory effect on radicle length this is in agreement with the results of Stachon et al. ${ }^{25}$ which reported that the extracts of allelopathic plants had more inhibitory effect on the root growth than on hypocotyl growth because root is the first organ to absorb allelochemical from the environment. Similar kinds of results were reported by Chon et al. ${ }^{25}$ Root length was the best indicator of allelopathic effects of plant extracts because root growth has been reported to be more sensitive to phytotoxic compounds than hypocotyl growth in alfalfa.

\section{Plumule (Shoot length)}

There was no significant difference in the plumule length of Zea mays $(\mathrm{P}>0.05)$. The plumule length was not affected by the extracts of $L$. clavatum. With time passing, the plumule length increased over the measurement period. The highest plumule length was observed in $25 \%$ concentration. Increase in plumule length could be justified with the work of Nishidia et al. ${ }^{26}$ who reported that the permeability of allelochemicals to root tissue was greater than that of shoot tissue. This shows that the extracts have stimulatory effect on plumule length of Zea mays. 


\section{Conclusion}

The study of the allelopathic effect of $L$. clavatum showed that the extract had significant effect $(\mathrm{P}<0.05)$ on the radicle growth of Zea mays whereas there was no significant effect in the plumule growth It is concluded that the extract of $L$. clavatum had both inhibitory and stimulatory effects on seedling growth of Zea mays.

\section{Recommendation}

There is need for further studies on the allelopathic effect of $L$. clavatum using different concentrations, solvent, method of extraction and volume of extract different from the one used in this research study to test its effects on Zea mays. It is also suggested that further research on the allelopathic effect of this extract should be done to test its effects on other cereal crops.

\section{Acknowledgements}

None.

\section{Conflict of interest}

The author declares no conflict of interest.

\section{References}

1. Rice EL. Allelopathy. 2nd ed. UK: Academic Press; 1984. p. 309-316

2. Bonner J. The role of toxic substances in interaction of higher plants Botanical Review. 1950;16(1):51-65.

3. Grummer G, Beyer H. The influence exerted by species of flax by means of toxic substances. In: Harper JL editor. The Biology of Weeds, UK: Blackwell; 1960. p.153-157.

4. Whittaker RH. The biochemical ecology of higher plants. In: Sondheimer E, et al. editors. Chemical Ecolog, USA: Academic Press; 1970. p. 43-70.

5. Putman AR, Duke WB. Allelopathy in agroecosystems. Annual Review of Phytopathology. 1978;16:431-451.

6. Fischer RF, Woods RA, Glavicic MR. Allelopathic effects of goldrod and ashes on young sugar maple. Canadian Journal of Forest Research. 1978;8:1-9.

7. Seigler DS. Allelopathy. Journal of Agronomy. 1996;88:876-885.

8. Einhellig FA. Interactions involving allelopathy in cropping systems Agronomy Journal. 1996;88(6):886-893.

9. Parvez SS, Parvez MM, Fujii Y, et al. Differential allelopathic expression of bark and seed of Tamarindus indica L. Plant Growth Regulation. 2004;42(3):245-252.

10. Kil JH, Shim KC. Allelopathic effects of Tagetes minuta L. and Eupatorium rugosum Houtt. Aqueous extracts on seedling growth of some plants. Allelopathy Journal. 2006;18:315-322.

11. Weir TL, Park SW, Vivanco JM. Biochemical and physiological mechanisms mediated by allelochemicals. Curr Opin Plant Biol. 2004;7(4):472-479.
12. Singh HP, Batish DR, Kohli RK. Allelopathic interactions and allelochemicals: Ne possibilities for sustainable weed management. Critical Reviews in Plant Science. 2003;22(3-4):239-311.

13. Abrahim D, Braguini WL, Kelmer-Bracht AM, et al. Effects of four monoterpenes on germination, primary root growth, and mitochondrial respiration of maize. Journal of Chemical Ecology. 2000;26(3):611-624.

14. Dayan FE, Watson SB, Galindo JCG, et al. Phytotoxicity of quassinoids: physiological responses and structural requirements. Pesticide Biochemistry and Physiology. 1999;65(1):15-24.

15. Romagni JG, Allen SN, Dayan FE. Allelopathic effects of volatile cineoles on two weedy plant species. Journal of Chemical Ecology. 2000;26(1):303-313.

16. Pires NM, Souza IRP, Prates HT, et al. Effect of aqueous leucine extract on the development, mitotic index and peroxidase activity in corn seedlings. Brazilian Journal of Plant Physiology. 2001;13(1):55-65.

17. Iganci JRV, Bobrowski VL, Heiden G, et al. Effect of the aqueous extract of different boldo species on the germination and mitotic index of Allium cepa L. Archives of the Biological Institute. 2006;73(1):79-82.

18. Linda CF. Corn in Andrew. In: Smith F editor. The Oxford Encyclopedia of Food and Drink in America. 2nd ed. USA: Oxford University Press; 2013. p. 1-553.

19. Kaur H, Inderjit S, Kaushik S. Cellular evidence of allelopathic interference of benzoic acid to mustard (Brassica juncea L.) seedling growth. Plant Physiology and Biochemistry. 2005;43(1):77-81.

20. Shivani T, Sunita K. Allelopathic effect of some liverworts on seed germination of the weed bidens pilosa L. International Journal of Pharmaceutical Sciences Review and Research. 2015;32(1):77-80.

21. Cruz-Ortega R, Anaya AL, Hernández-Bautista BE, et al. Effects of allelochemical stress produced by on seedling root ultrastructure of Phaseolus vulgaris and Cucurbita fi cifolia. Journal of Chemical Ecology. 1998;24(12):2039-2057.

22. Waris A, Waris L, Khan MA, et al. Allelopathic Effect of Methanol and Water Extracts of Camellia sinensis L. on Seed Germination and Growth of Triticum aestivum L. and Zea mays L. Journal of Bioresource Management. 2014;3(1):15-21.

23. Gatti AB, Alfredo GF, Marcos Arduin, et al. Allelopathic effects of aqueous extracts of Artistolochia esperanzae on development of Sesamum indicum L. seedlings. Journal of Acta botania brasilica. 2010;24(2):454-461.

24. Chaudhuri A, Ray S. Determination of effective allelopathic (inhibitory) extract fractions of Ampelocissus latifolia (Roxb.) Plant leaf. European Journal of Experimental Biology. 2015;5(8):1-7

25. Stachon WJ, Zimdahl RL. Allelopathic activity of Canada thistle Cirsium arvense in Colorado. Weed Science. 1980;28(1):83-86.

26. Nishidia N, Tamotsu S, Matata N, et al. Allelopathic effects of volatile monoter penoids produced by Salvia leucophylla: Inhibition of cell proliferation and DNA synthesis in the root apical meristem of Brassica campestris seedlings. J Chem Ecol. 2005;3(5):1187-1203. 